Original scientific paper

\title{
REGIONAL CHARACTERISTICS OF MARKET PRODUCTION OF FRUIT AND GRAPES IN SERBIA ${ }^{1}$
}

\author{
Simo Stevanovič́, Snežana Stevanović ${ }^{3}$, Svjetlana Janković-Šsoja ${ }^{4}$
}

\section{Summary}

In the paper analyzes the trends in the development of market production of fruit (on the example of the apple and the plum) and grapes in Serbia from 1976 to 2015. The grouping of the Serbian districts according to the degree of the market production of fruit and grapes in 2015 was performed by a cluster analysis, on the basis of the six features of production, five features of the capacities, and five features of development.

According to the data for 2015, the degree of the marketability of apples in Serbia was 47.7\%, plums 15.9\%, and grapes 18.3\%. The Serbia-North Region shows a surplus in the production of apples, and a deficit in the production of plums (-181.7\%) and grapes (-99.1\%). The Serbia-South Region has a surplus in the production of the analyzed kinds of fruit (the apple accounting for $43.0 \%$, and the plum $50.9 \%$ ) and grapes $(45.2 \%)$.

Keywords: market production of fruit, economic development, I-distance, cluster analysis JEL: $Q-13, O-11$

\section{Introduction}

Serbia is a traditionally significant producer of all kinds of continental fruit and grapes. Given the commercial, technological and nutritive characteristics of fruit production,

1 The paper is part of the research conducted on the "Serbia's Rural Labor Market and Rural Economy - Income Diversification and Poverty Reduction" Project, No. ON179028, which has been funded by the Ministry of Science and Technological Development of the Government of the Republic of Serbia since 2011.

2 Simo Stevanović, Ph.D., Full Professor, University of Belgrade, Faculty of Agriculture, Nemanjina 6, 11080 Belgrade, Republic of Serbia, phone: +381114413418 , e-mail: simo. stevanovic@agrif.bg.ac.rs.

3 Snežana Stevanović, Ph.D., Assistant Professor, University of Belgrade, Faculty of Agriculture, Nemanjina 6, 11080 Belgrade, Republic of Serbia, phone: +381114413226, e-mail: smasovic@agrif.bg.ac.rs.

4 Svjetlana Janković-Šoja, Ph.D., Assistant Professor, University of Belgrade, Faculty of Agriculture, Nemanjina 6, 11080 Belgrade, Republic of Serbia, phone: +381114413419 , e-mail: svjetlanajs@agrif.bg.ac.rs.

EP 2018 (65) 1 (201-214) 
its development strongly influences the development of not only primary agricultural production and agroindustry, but also the overall economy and especially the rural areas and the country as a whole (Đorović et al., 2008). Fruit growing unites, on the one hand, requirements for the production of ecologically healthy food, whereas on the other, those for the protection of the living environment. In that manner, it becomes an important factor of the improvement of the production of healthy food and the management of the quality of the population's nutrition.

In nutrition, fruits are an important source of vitamins, minerals, and the other ingredients necessary for an organism, which determine the quality of the nutrition of the population of a country. Therefore, the consumption of fruit significantly ranks in the structure of balanced diet. Fruit is a "source of health", an organism's resistance (immunity), physical and mental strengths. The advantage of consuming it reflects in the fact that it is frequently used fresh, directly and without thermal processing, during which precious substances that fruit is rich in are lost (Tomić, 2008).

The great significance of fruit growing reflects in the following: the irreplaceability of fruits in a population's nutrition ${ }^{5}$; raw materials in the development of the food industry and other accompanying activities; the export of fresh or unprocessed fruit to a foreign market; a more balanced utilization of the labor force during the year; a high profit as per unit of area; the utilization of natural resources; combating the erosion of soil; changes in microclimates, the development of bee growing and wood pulp ${ }^{6}$ (Božić, 2005).

An increase in the national income and demand for food products leads to an increase in the consumption of fruits and grapes in their fresh and processed state on the domestic market $^{7}$. Several factors have influenced the growth of demand for fruit, as the basic driver of the development of fruit growing and growth in the marketability of this branch, as well as an increase in the volume of fruit production. Specially significant are the growth of income per capita, changes in the socioeconomic structure of the population in favor of non-agricultural and mixed, the development of the culture of nutrition and habits in fruit consumption, etc. Especially significant is an increase in the consumption of fruit due to the process of the diversification of processing and the emergence of new fruit products ${ }^{8}$.

5 The World Health Organization suggests that, in the structure of the population's nutrition daily energy needs, fruits should account for about 3\%. (Božić, 2005).

6 Technical wood, suitable as a raw material for processing (walnut, pear, plum, cherry) and firewood.

7 The consumption of fruit and table grapes oscillates from one year to another, depending on yields, is relatively small and of an unfavorable structure. According to the available statistical data, the consumption of fresh fruit and grapes per capita ranges between 50 and 65 kg. (Đorović et al., 2010).

8 Fruit juices, jams, various pulps, fruit wines, pasteurized and dried fruits, concentrates, candied fruits, brandies of different standards and qualities, products in combination with pastries, yoghurts, ice-creams, chocolate-fruit, confectionaries, etc. 
In fruit production, the two tendencies are becoming apparent in the movement and usage of product capacities. On the one hand, the number of fertile trees is increasing, whereas on the other, there is a fluctuation of the areas under orchards. As a result of the policy of stimulating the development of fruit growing in the social sector, until the mid-1980s, there was a tendency for the areas under orchards to increase. The deterioration in the economic conditions was weakening the motive for expanding the production capacities in the social sector. On the other hand, due to the pronounced processes of degrading fruit production, especially with the farming households that had been left without active labor force, fruit plantations were being cleared (Simić et al., 1994). The instability of the movement of the volume of fruit and wine-growing production was influenced by both economic and natural factors.

Even though there has been an ever-increasing influence of growing demand, the diversification of processing and an increase in the processing capacities, traditional factors, such as annual and occasional variations in the climatic conditions, the slow changing of the extensive methods of growing, the insufficient economic motivation of farming households to invest their capital and raise contemporary plantations, etc. still have a significant influence. Even apart from the foregoing, Serbia still has favorable ecological conditions, not only for the traditional production of the apple and the plum, but also for the production and processing of other kinds of fruit and grapes.

The development of the market production of fruit and grapes is influenced by the crop changes that have been made on the world economic scene, the recessive tendencies and the contradictions of the development of agriculture under the influence of business, systemic, economic and ecological determinants, especially during the transition period. For that reason, there is a need for determining the factors of the development of the market production of fruit and grapes in the transition period and the changed external and internal market environment.

In the paper, we start from the hypothesis that, in Serbia, there is a pronounced regionalization of the production of fruit and grapes, especially in we bear in mind the degree of the dependence of these productions on natural conditions. Therefore, we can speak about a pronounced regionality of the production of each of the analyzed kinds of fruit and grapes. The presence of these productions, especially an increase in the degree of marketability, has a positive influence of overall agriculture, i.e. the economic development of the Serbian districts.

The goal of the paper is to analyze the development of the market production of fruit and grapes as per Serbian districts, on the basis of the three groups of features: production, capacities and development. Based on these features, the I-distance (Ivanović's Distance) was applied to rank the Serbian districts.

The results of researching the features of production, capacities and development represent a good ground for the implementation of the production regionalization and conducting a joint agrarian policy as per the districts that belong to the same cluster. 


\section{Methods of Work and Data Sources}

By analyzing the production of fruit and grapes as per Serbian districts, it was determined that there is a connection between the volume of production, the available capacities and the development level.

While carrying out the analysis of the production of fruit and grapes, the territorial organization of Serbia was taken into consideration. Serbia's territory is shown according to the Regulation on the Nomenclature of Statistical Territorial Units? (Devetaković, 2008) With respect to its territorial organization, Serbia applies the EU standards in the domain of statistical organizing (NUTS and LAW Levels). The NUTS-1 Level of Serbia encompasses 2 regions (Serbia-North and Serbia-South). The NUTS-2 Level encompasses 5 regions (Vojvodina Region, Belgrade Region, Region of Šumadija and West Serbia, Region of Southern and Eastern Serbia and Region of Kosovo and Metohija). The NUTS-3 Level encompasses 25 districts, and the NUTS-4 Level encompasses Serbian municipalities.

The ranking of the districts by applying the I-distance Method was performed on the basis of the three groups of features: a) production (6, from $\mathrm{x}_{1}$ to $\left.\mathrm{x}_{6}\right)$ : $\mathrm{x}_{1}$-apple production as per districts, $\mathrm{x}_{2}$-plum production as per districts, $\mathrm{x}_{3}$-grape production as per districts, $\mathrm{x}_{4}$-the apple marketability degree as per districts, $\mathrm{x}_{5}$-the plum marketability degree as per districts, $\mathrm{x}_{6}$-the grapes marketability degree as per districts, $\left.\mathrm{b}\right)$ capacities $\left(5\right.$, from $\mathrm{x}_{7}$ to $\left.\mathrm{x}_{11}\right): \mathrm{x}_{7}$-the number of the apple fertile trees as per districts, $\mathrm{x}_{8}$-the number of the plum fertile trees as per districts, $x_{9}$-the number of the fertile vine stocks as per districts, $x_{10}$ the share percentage of the areas under orchards, $x_{11}$-the share percentage of the areas under vineyards, and c) the development level $\left(5\right.$, from $\mathrm{x}_{12}$ to $\left.\mathrm{x}_{16}\right)$ : $\mathrm{x}_{12}-\mathrm{NI} /$ per capita, $\mathrm{x}_{13}$-the percentage of the non-agricultural population, , $\mathrm{x}_{14}$-the percentage of an increase/ decrease in the number of the population in 2015 in comparison with 2002, $\mathrm{x}_{15}$-the share of agriculture in the NI of the economy, and $x_{16}$-the share of industry in the NI of economy.

On the basis of the data as per municipalities, a fact was established that there is a significant difference between the mean value and the median calculated for the data at the district level because the analyzed features as per municipalities do not represent a normal distribution of the data at the district level. Because of that, the ranking of the districts according to the analyzed features was performed on the basis of the medial value as per municipalities. (Stevanović et al., 2016, Lakić et al., 2003)

For each of the mentioned groups of features (production, capacities, development), the I-distance (Ivanović, 1973, 1977, Ivanović et al., 1973, Docampo, 2011, Jeremić, 2012, Hauner et al., 2010, Nita, 2011) was applied to perform the ranking of the districts from 1 to 25 (Rank 1-the best, Rank 25-the worst).

$$
D_{k}=\sum_{i=1}^{n} \frac{\left|X_{1 k}-X_{1}^{-}\right|}{s_{1}} \prod_{j=1}^{i=1}\left(1-r_{i j}\right)
$$

9 Official Gazette of the RS, No. 109/09 and 46/10. 
By applying the cluster analysis, the homogenous groups of districts in Serbia were defined from the point of view of the volume of the production of fruit and grapes. The similarities between the districts, according to the analyzed features, were defined by the Euclidian measure of distance, whereas the complete linkage method was used to group the Serbian districts. The obtained results of the hierarchical classification are displayed by a dendrogram.

For the analysis of the production and capacities features $\left(\mathrm{x}_{1}-\mathrm{x}_{11}\right)$, the data stated in the publication entitled Municipalities in the Republic of Serbia in 2015, published by the Statistical Office of the Republic of Serbia, were used. Since 2006, the data about the development level feature $\left(\mathrm{x}_{12}-\mathrm{x}_{16}\right)$ as per districts have not been published, so for those features the publication entitled Municipalities in the Republic of Serbia in 2005 were used.

\section{Results and Discussion}

In economic development, agriculture provided accumulation and labor force for the development of non-agricultural activities, the production of raw materials for the processing industries, the users of the output of industrial products, whereas the export of agricultural products used to serve to reduce the deficit in the country's foreign-trade balance. Economic development, too, had a positive impact on the development of agriculture, which is reflected in the changing of its structure, i.e. through the growth of the share of highly-accumulative productions (fruit growing, vine growing, cattle breeding, etc.) in the economic structure. For that reason, agriculture is said to be playing a multifunctional role in economic development.

Because of the comparative microclimatic conditions, Serbia has for long been recognized as a vine-growing country. There are areas differentiated as traditional winehills, which are known as the regions where quality wine is produced today. (Vlahović et al., 2006)

In the period from 1976 to 2015 (Graph 1), the number of the fertile apple trees increased by 1.8 times, from 9.6 to 16.8 trees (i.e. the $1.9 \%$ growth rate). The volume of the apple production increased by $23.2 \%$, from 190.7 to 234.5 thousand tons (the $0.6 \%$ growth rate), whereas the yield of apples as per tree decreased by $29.7 \%$, from 19.8 to 13.9 $\mathrm{kg}$ (the $-1.3 \%$ growth rate). The decrease in the yield as per tree was a consequence of shifting to growing apples in a contemporary manner. The number of the fertile apple trees ranged from the minimal 8.7 to the maximal 18.4 million, the production ranged from 95.6 to 307.0 thousand tons, and the yield as per tree from 6.0 to $26.0 \mathrm{~kg}$. The average annual fluctuation (standard deviation) in the number of the apple trees was 2.1 million, 42.7 thousand tons in production, and $3.9 \mathrm{~kg}$ in the yield as per tree.

The number of the fertile plum trees decreased by $24.8 \%$, from 49.6 to 40.1 million trees (the $-0.7 \%$ growth rate). The volume of the plum production was reduced by $17.9 \%$, from 442.1 to 416.6 thousand tons (the $-0.5 \%$ growth rate), whereas the yield of plums as per tree increased by $16.3 \%$, from 8.9 to $10.4 \mathrm{~kg}$ (the $0.4 \%$ growth rate). The 
average annual fluctuation (standard deviation) in the number of the plum trees was 3.4 million, 120.6 thousand tons in production, and $2.9 \mathrm{~kg}$ in the yield as per tree. In the analyzed period, the number of the plum fertile trees ranged from the minimal 37.1 to the maximal 50.4 million, production ranged from 197.5 to 662.6 thousand tons, and the yield as per tree from 4.0 to $15.9 \mathrm{~kg}$.

The number of the fertile vine stocks decreased by $65.2 \%$, from 622.0 to 265.2 million vine stocks (the $-2.7 \%$ growth rate). The volume of the grape production was reduced by $44.2 \%$, from 451.7 to 301.9 thousand tons ( $-1.4 \%$ growth rate), whereas the yield of grapes as per vine stock increased by $71.4 \%$, from 0.7 to $1.1 \mathrm{~kg}$ (the $1.4 \%$ growth rate). The average annual fluctuation (standard deviation) in the number of the fertile grape stocks was 112.6 million, 89.6 thousand tons in production, and $0.2 \mathrm{~kg}$ in the yield as per stock. In the analyzed period, the number of the fertile grape stocks ranged from the minimal 225.5 to the maximal 648.0 million, the production ranged from 182.9 to 630.4 thousand tons, and the yield as per stock from 0.4 to $1.5 \mathrm{~kg}$.

Graph 1. Fertile trees/stocks and the production of apples, plums and grapes in Serbia in the period from 1976 to 2015

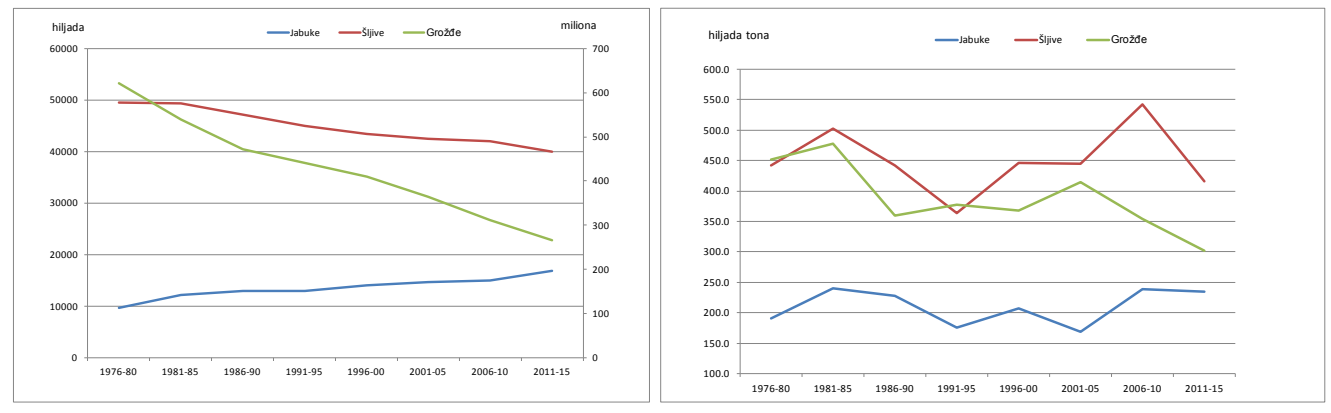

Source: Processed by the Author on the basis of the data from the Statistical Office of the Republic of Serbia, Belgrade.

There are big differences in the presence of fruit growing and vine growing as per Serbian regions, not only with respect to the areas, but also with respect to the number of fertile trees/stocks and the kinds of fruit and grapes. According to the data for 2015, the areas under orchards in Serbia accounted for 156.7 thousand ha, i.e. $4.56 \%$, whereas those under vineyards accounted for 22.5 thousand ha, i.e. $0.64 \%$, of the total agricultural areas.

One-half of the total apple production is achieved in the three districts (North Bačka 13.5\%, South Banat 11.0\% and South Bačka 10.1\%) of Vojvodina Region, and one district (Danube-Basin 14.0\%) of the Region of Southern and Eastern Serbia. Apart from these, the apple production districts are Srem District, accounting for $8.8 \%$; Belgrade District, accounting for $6.0 \%$, and Zlatibor District, accounting for 5.7\%. One-third of the total plum production is generated from the three districts (Mačva District 11.3\%, Kolubara District 11.1\% and Sumadija District 10.5\%) of the Region of Šmadija and Western Serbia. As the more significant districts producing plums, 
the following ones should be mentioned: Toplica District 8.5\%, Morava-Basin District 6.1\%, Nišava District 5.6\% and Moravica District 5.4\%. Also, one-third of the total grape production is generated from the two districts (Jablanica District $10.8 \%$ and Bor District 10.1\%) of the Region of Southern and Eastern Serbia, and one district (Rasina District $10.7 \%$ ) of the Region of Šumadija and Western Serbia. The grape production districts worthy of mentioning are also Nišava District 9.1\%, Morava-Basin District 7.7\%, Srem District 6.7\% and Zaječar District 6.3\%.

Table 1. The production of fruit and grapes and the marketability degree as per Serbia's regions and districts in 2015

\begin{tabular}{|c|c|c|c|c|c|c|}
\hline \multirow{2}{*}{ Actually } & \multicolumn{3}{|c|}{ Production in $\mathrm{t}$} & \multicolumn{3}{|c|}{ Marketability degree in \% } \\
\hline & Apple & Plum & Grapes & Apple & Plum & Grapes \\
\hline Republic of Serbia & 332255 & 738278 & 320329 & 47.7 & 15.9 & 18.3 \\
\hline I Serbia - North & 180778 & 110941 & 82847 & 51.6 & -181.7 & -59.1 \\
\hline I-1 Belgrade region & 19783 & 34197 & 16041 & -108.0 & -329.8 & -286.4 \\
\hline I-2 Vojvodina region & 160995 & 76744 & 66806 & 71.2 & -115.7 & -4.5 \\
\hline 1.2.1 West Bačka district & 6552 & 7860 & 4157 & 32.8 & -100.0 & -59.5 \\
\hline 1.2.2 South Banat district & 36495 & 9509 & 13543 & 80.8 & -162.8 & 22.2 \\
\hline 1.2.3 South Bačka district & 33416 & 8025 & 11477 & 54.8 & -572.4 & -98.3 \\
\hline 1.2.4 North Banat district & 2486 & 6603 & 6874 & -39.6 & -87.7 & 24.0 \\
\hline 1.2.5 North Bačka district & 44919 & 12271 & 4269 & 90.0 & -30.1 & -57.7 \\
\hline 1.2.6 Central Banat district & 7766 & 8021 & 5179 & 43.0 & -97.2 & -28.8 \\
\hline 1.2.7 Srem district & 29361 & 24455 & 21307 & 74.6 & -9.1 & 47.2 \\
\hline II Serbia - South & 151477 & 627337 & 237482 & 43.0 & 50.9 & 45.2 \\
\hline $\begin{array}{l}\text { II-1 Region of Šumadija and } \\
\text { Western Serbia }\end{array}$ & 64618 & 424029 & 77610 & 25.2 & 59.3 & 6.2 \\
\hline 2.1.1 Zlatibor district & 19010 & 35878 & 0 & 64.4 & 32.6 & 0.0 \\
\hline 2.1.2 Kolubara district & 3237 & 81984 & 452 & -27.4 & 82.0 & -1273.9 \\
\hline 2.1.3 Mačva district & 7230 & 83205 & 2324 & 2.4 & 69.7 & -357.3 \\
\hline 2.1.4 Morava district & 10132 & 39597 & 434 & 50.3 & 54.6 & -1648.3 \\
\hline 2.1.5 Pomoravlje district & 6615 & 44914 & 24656 & 23.5 & 59.8 & 69.1 \\
\hline 2.1.6 Rasina district & 5623 & 34999 & 34272 & -1.2 & 41.9 & 75.0 \\
\hline 2.1.7 Raška district & 6368 & 25872 & 154 & -18.3 & -4.0 & -7265.8 \\
\hline 2.1.8 Šumadija district & 6403 & 77580 & 15318 & -10.1 & 67.5 & 30.7 \\
\hline $\begin{array}{l}\text { II-2 Region of Southern } \\
\text { and Eastern Serbia }\end{array}$ & 86859 & 203308 & 159872 & 56.2 & 33.2 & 64.2 \\
\hline 2.2.1 Bor district & 2197 & 3897 & 32370 & -32.0 & -165.8 & 86.5 \\
\hline 2.2.2 Braničevo district & 6359 & 18472 & 14201 & 32.6 & 17.2 & 54.6 \\
\hline 2.2.3 Zaječar district & 3242 & 12499 & 20043 & 14.5 & 20.8 & 79.2 \\
\hline 2.2.4 Jablanica district & 5795 & 24373 & 34545 & 12.3 & 25.5 & 77.8 \\
\hline 2.2.5 Nišava district & 7583 & 41589 & 29290 & -18.9 & 22.6 & 53.6 \\
\hline 2.2.6 Pirot district & 2784 & 14388 & 9090 & 22.5 & 46.4 & 64.2 \\
\hline 2.2.7 Podunavlje district & 46545 & 10411 & 11035 & 89.8 & -62.2 & 35.5 \\
\hline 2.2.8 Pčinja district & 4778 & 14657 & 2601 & -3.2 & -20.1 & -185.4 \\
\hline 2.2.9 Toplica district & 7576 & 63022 & 6697 & 71.7 & 87.9 & 51.8 \\
\hline
\end{tabular}

Source: Processed by the Author on the basis of the data from the Statistical Office of the Republic of Serbia, Belgrade.

The marketability of apple production in Serbia is around 55\%. $40 \%$ of annual production is encompassed by total purchase. About $15 \%$ of the annual production of apples is circulated through the peasant marketplace. The analysis of the structure of the consumption of plums shows that about $70 \%$ of the total produced quantities are 
turned to brandy ${ }^{10}$, about $12 \%$ are dried, about $10 \%$ are consumed in the fresh state, and around $8 \%$ are processed ${ }^{11}$. (Đorović et al., 2010) In the grape production structure, table grapes are estimated to account for around $20 \%$, and wine ones around $80 \%$. The marketability of the production has had a significant fall, namely from as much as $15.5 \%$ to merely $2 \%$. About $1.8 \%$ of annual production is encompassed by total purchase, whereas approximately $0.9 \%$ is circulated through the peasant marketplace. (Đorović et al., 2008)

According to the data for the year 2015, the marketability degree ${ }^{12}$ of the apple was $47.7 \%, 15.9 \%$ was that of the plum, and that of grapes accounted for $18.3 \%$. The Region of Serbia-North shows a $51.6 \%$ surplus in the production of apples, and a deficit of $-181.7 \%$ in the production of plums and $-59.1 \%$ in the production of grapes. The Region of Serbia-South recorded a surplus in both of the analyzed kinds of fruit (the apple 43.0\%, the plum 50.9\%) and grapes 45.2\%. Beside Belgrade District, which recorded a deficit, all of the analyzed kinds of fruits and grapes (the apple $-108.0 \%$, the plum $-329.8 \%$ and the grapes $-286.4 \%$ ), adding to it yet 8 districts (North Banat District $-39.6 \%$, Kolubara District $-27.4 \%$, Raška District $-18.3 \%$, Šumadija District $-10.1 \%$, Nišava District $-18.9 \%$, Bor District $-32.6 \%$, Pčinja District $-3.2 \%$ and Rasina District $-1.2 \%$ ), demonstrated a deficit in the production of apples, ranging from $-3.2 \%$ to $-39.6 \%$. A deficit in the production of plums was recorded in all the 7 districts of Vojvodina Region, ranging fron $-9.1 \%$ in Srem District, to $-572.4 \%$ in South Bačka District. In yet other four districts of the Region of Serbia-South there was a deficit in the production of plums, ranging from $-4.0 \%$ in Raška District to $-165.8 \%$ in Bor District. Only the 3 (South Banat District 22.2\%, North Banat District 24.0\% and Srem District $47.2 \%$ ) of the 8 districts of the Region of Serbia-North recorded a surplus in grape production. The deficit in the production of this region ranged from $-4.5 \%$ in West Bačka District to $-286.4 \%$ in Belgrade District. Due to unfavorable soil and climate conditions, in the 4 (Zlatibor, Kolubara, Moravica and Raška Districts) of the 8 districts of the Region of Šumadija and Western Serbia, the production of grapes was not, or was but only symbolically, present. With the exception of the Pčinja District, in which the grape production deficit was $-185.4 \%$, the other 8 districts of the Region of Southern and Eastern Serbia recorded a surplus in the production of grapes of $35.5 \%$ in the Danube-Basin District, up to $79.2 \%$ in Zaječar District.

Differently from the apple and the plum, the production of grapes has a more pronounced regional expansion. Due to favorable microclimatic, orographic and soil conditions, the following are Serbia’s famous wine hills: Negotinska Krajina, Fruška Gora Mountain, Župa Valley, and Vršac Hill.

10 In the analysis of the marketability of the production of plums, we started from the fact that the plum turned into brandy is realized on the market in a significant quantity, whereas only small amounts of brandy are retained for household needs.

11 By industrial or domestic processing, marmalade, jam, compote, juice, etc. are produced.

12 ((production surplus)/total production)*100 


\section{Cluster Analysis of Fruit and Grape Production in Serbia}

By calculating the I-distance for the capacities, production and development level features, the ranking of the districts of fruit and grape production in Serbia was performed.

Table 2. The ranks of the districts of the production of fruit and grapes in Serbia according to the I-distance

\begin{tabular}{|l|c|c|c|c|c|c|}
\hline \multirow{2}{*}{ Districts } & \multicolumn{2}{|c|}{$\begin{array}{c}\text { Capacities } \\
\text { Features }\end{array}$} & \multicolumn{2}{c|}{$\begin{array}{c}\text { Production } \\
\text { features }\end{array}$} & \multicolumn{2}{c|}{$\begin{array}{c}\text { Development } \\
\text { Level Features }\end{array}$} \\
\cline { 2 - 7 } & I-distance & Rank & I-distance & Rank & I-distance & Rank \\
\hline Rasina district & 30.98 & 1 & 48.32 & 2 & 8.78 & 16 \\
\hline Podunavlje district & 27.49 & 2 & 64.54 & 1 & 7.80 & 17 \\
\hline Toplica district & 16.25 & 3 & 44.35 & 3 & 3.96 & 22 \\
\hline Morava district & 16.21 & 4 & 41.88 & 4 & 11.40 & 11 \\
\hline Šumadija district & 8.09 & 5 & 41.53 & 5 & 10.54 & 13 \\
\hline Nišava district & 6.10 & 6 & 38.33 & 8 & 4.98 & 20 \\
\hline Mačva district & 4.88 & 7 & 39.63 & 7 & 3.48 & 23 \\
\hline Pomoravlje district & 4.66 & 8 & 40.49 & 6 & 9.63 & 15 \\
\hline Kolubara district & 4.61 & 9 & 29.11 & 21 & 5.71 & 19 \\
\hline Zlatibor district & 3.92 & 10 & 26.91 & 22 & 10.01 & 14 \\
\hline Zaječar district & 3.37 & 11 & 36.56 & 9 & 3.20 & 24 \\
\hline Jablanica district & 3.15 & 12 & 32.50 & 18 & 10.62 & 12 \\
\hline Jablanica district & 2.99 & 13 & 36.14 & 11 & 3.07 & 25 \\
\hline Raška district & 2.90 & 14 & 32.54 & 17 & 15.35 & 6 \\
\hline Pirot district & 2.09 & 15 & 33.92 & 15 & 18.57 & 5 \\
\hline Srem district & 1.52 & 16 & 36.53 & 10 & 11.97 & 9 \\
\hline Braničevo district & 1.16 & 17 & 35.35 & 12 & 4.83 & 21 \\
\hline Pčinja district & 0.76 & 18 & 31.85 & 20 & 7.75 & 18 \\
\hline Central Banat district & 0.38 & 19 & 34.04 & 14 & 12.88 & 7 \\
\hline West Bačka district & 0.37 & 20 & 34.30 & 13 & 22.50 & 2 \\
\hline Belgrade district & 0.22 & 21 & 0.00 & 25 & 60.14 & 1 \\
\hline South Banat district & 0.12 & 22 & 32.01 & 19 & 12.19 & 8 \\
\hline North Bačka district & 0.07 & 23 & 23.15 & 23 & 11.61 & 10 \\
\hline South Bačka district & 0.05 & 24 & 32.68 & 16 & 19.16 & 4 \\
\hline North Banat district & 0.02 & 25 & 20.72 & 24 & 20.53 & 3 \\
\hline
\end{tabular}

Source: Calculation done by the Author on the basis of the data from the Statistical Office of the Republic of Serbia, Belgrade.

The production of apples and plums is present in all of the 25 districts and that of grapes in 21. There are significant differences in the ranks of the districts of the production of apples, plums and grapes, according to the capacities, production and the development level features (Table 2). The ranks of the first 8 districts according to the capacities and production features have the identical orders, but according to the development features, they belong to the different ranks, from 11 to 24 . The said is indicative of the fact that, according to the development features, the districts of the production of apples, 
plums and grapes belong to less developed areas, i.e. they are not directly correlated with the development level features. The previously mentioned is also confirmed by the 4 most developed districts, according to the development level features (Belgrade, West Bačka, North Bačka and South Bačka Districts). According to the capacities features, these districts belong to the ranks 20,21, 24 and 25, whereas according to the production features, they belong to the ranks 13, 16, 24 and 25.

In the dendrogram (Graph 2), the 3 clusters of the districts of the production of apples, plums and grapes in Serbia are identified. The most numerous is the third cluster, encompassing 13 districts, and is followed by the second, encompassing 8 districts, and the first, only encompassing 4 districts.

Graph 2. The dendrogram of the production of apples, plums and grapes as per districts in Serbia

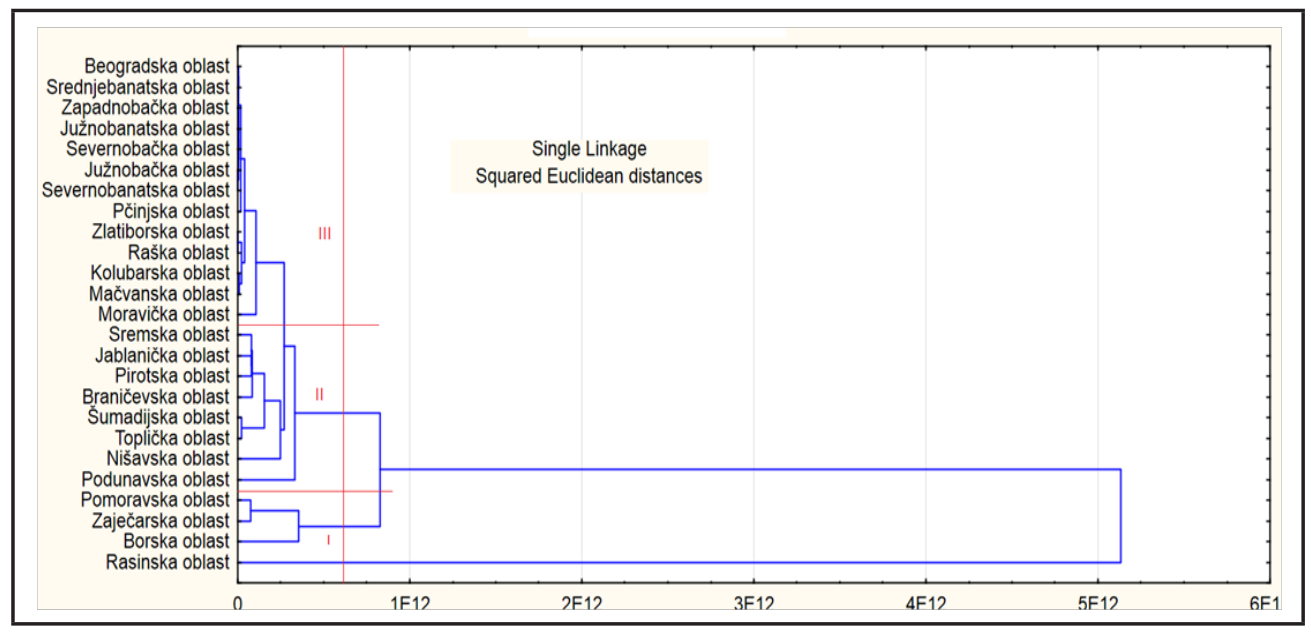

The first cluster includes 4 districts, two from each of the Region of Sumadija and Western Serbia (Morava River Basin and Rasina Districts) and the Region of Southern and Eastern Serbia (Bor and Zaječar Districts). The districts of this cluster are the regions known for grape production. According to the features of the grape production capacities, the districts of this cluster belong to the ranks 1-4, according to the grape production features to the ranks 1-5, and according to the amount of the NI/per capita to the ranks 11 (Morava Basin District) to 23 (Bor District). The marketability of the grape production of this cluster is high and belongs to the ranks 1-6. According to the plum production features, the districts of this cluster belong to the ranks from 5 (Morava Basin District) to 22 (Bor District). The situation is similar when the apple production features are concerned, where the same mentioned districts belong to the ranks from 8 (Morava River Basin District) to 21 (Bor District).

The second cluster includes 8 districts, the 6 districts (Braničevo, Jablanica, Nišava, Pirot, Danube-Basin and Toplica Districts) of the Region of Southern and Eastern Serbia, 1 district (Šumadija District) of the Region of Šumadija and Western Serbia, 
and 1 district (Srem District) of Vojvodina Region. According to the apple production features, the districts of this cluster belong to the ranks 1 (Danube-Basin District) to 20 (Pirot District). The ranks of the apple production capacities are worse than the ranks of the production features, which is indicative of the fact that there is intensive apple production taking place in these districts. The exceptions are the Danube-Basin Distric (Rank 1) and Toplica District (Rank 4), which have the same rank of the apple production and capacities features. According to the plum production features, the districts of this cluster belong to the ranks 4 (Šumadija District) to 19 (Pirot District), whereas according to the capacities features, they belong to the ranks 2 (Toplica District) to 16 (Srem District). With the exception of Šumadija District (Rank 9) and Srem District (Rank 10), according to the development level features, the fields of the second cluster mainly belong to the less developed districts (Ranks 16-24).

The third cluster is the most numerous. The thirteen districts belong to this cluster, of which 7 of the 8 districts in total of the Region of Serbia-South, 5 of the 8 districts of the Region of Šmadija and Western Serbia, and only 1 district of the Region of Southern and Eastern Serbia.

According to the apple production and capacities features, the districts of the third cluster belong to the ranks 2, 3 (Moravica District) to 25 (North Banat District). According to the plum production features, the districts belong to the ranks 1 (Mačva District) to 25 (Belgrade District), and also with respect to the capacities, they belong to the ranks 1 (Moravica District) to 25 (South Bačka District).

According to the development level features, they range from the most developed (West Bačka District - Rank 1, and Belgrade District - Rank 2) to the poorest districts (Pčinja District - Rank 25).

\section{Conclusion}

Studying the regional distribution of agricultural production is aimed at perceiving and maximally taking the comparative advantages and possibilities of a faster growth of the agriculture of some area in the biggest capacity in the market conditions of business doing. Simultaneously, the development of market production leads to the creation of the preconditions for a further development of both agriculture and the overall economy.

Due to specific orographic and climatic conditions, the production of grapes shows the biggest regional dependence, whereas the mentioned specificities are less pronounced in the production of apples and plums.

Of the 7 districts as the significant grape producers that account for $61.4 \%$ of the total production, the four belong to the first cluster. In the districts that belong to the first cluster, $34.8 \%$ of the total grape production in Serbia is realized. The stated data are indicative of the pronounced regionalization of grape production, which has also been confirmed by the dendrogram. 
In 6 (North Bačka, South Banat, South Bačka, Belgrade, Zlatibor, and Moravica Districts) of the 13 districts in total that belong to the third cluster, $48.3 \%$ of the total apple production is realized. Of that, $33.6 \%$ originates from the three districts of Vojvodina Region. The data are indicative of the fact that the districts that belong to the third cluster are significant apple producers.

Differently from grapes and apples, the production of plums is more regionally diversified. Not a single cluster of the three clusters is a region dominant in plum production. Yet, onehalf $(52.4 \%)$ of the total plum production is concentrated in the three $(27.8 \%)$ districts of the third cluster (Kolubara, Mačva and Moravica Districts) and the three (24.6\%) districts of the second cluster (Šumadija, Toplica and Nišava Districts).

The simple correlation coefficients ${ }^{13}$ of the apple, plum and grape production and the $\mathrm{NI} /$ per capita indicate a low negative degree of the dependence of these productions and the development levels. So, there is no interdependence between the production of apples, plums and grapes and the level of economic development.

\section{Literature}

1. Božić, Dragica (2005). Kvalitet ishrane stanovištva Evropske Unije i Srbije, Monografija, Društvo agrarnih ekonomista Srbije, Beograd, str. 1-230.

2. Devetaković, S. (2008). Regioni i regionalni razvoj u Srbiji danas, Tematski zbornik Ekonomska politika i privredni razvoj, Univerzitet u Beogradu, Ekonomski fakultet, Beograd, str. 75-90.

3. Docampo, D. (2011). On using the Shanghai ranking to assess the research performance of university systems, Scientometrics, 86(1), 77-92.

4. Đorović, M., Milanović, M., Stevanović, S. (2008). Istraživanje domaćeg tržišta voća, Tematski zbornik radova sa međunarodnog naučnog skupa: „Agroekonomska nauka i struka u tranziciji obrazovanja i agroprivrede“. 24-25. oktobar 2008, Poljoprivredni fakultet, Beograd-Zemun, str. 163-177.

5. Đorović, M., Milanović, M., Stevanović, S. (2009). Komparativna tržišna analiza svetske proizvodnje $i$ međunarodnog prometa voća, Ekonomika poljoprivrede, Beograd, 56(1), str. 13-29.

6. Đorović, M., Tomin, A. (2010). Tržište i promet poljoprivrednih proizvoda, Univerzitet u Beogradu, Poljoprivredni fakultet, Beograd, str. 1-476.

7. Hauner, D., \& Kyobe, A. (2010). Determinants of government efficiency, World Development, 38(11), 1527-1542.

8. Ivanović, B. (1973). A method of establishing a list of development indicators, Paris: United Nations educational, scientific and cultural organization.

9. Ivanović, B. (1977). Teorija klasifikacije, Institut za ekonomska istraživanja, Beograd.

10. Ivanović, B., Fanchette, S. (1973). Grouping and ranking of 30 countries of Sub-

13 Apple production-NI/per capita $=-0.0842161$, plum production-NI/per capita $=-0.2060879$, and grape production-NI/per capita $=-0.3112917$. 
Saharan Africa, Two distance-based methods compared, Paris: United Nations educational, scientific and cultural organization.

11. Jeremić, V. (2012). Statistical Efficiency Model Based on the Ivanovic Distance, University of Belgrade, Faculty of organizational sciences, Belgrade, (Doctoral Dissertation).

12. Lakić N, Stevanović S. (2003) Ranking of the Municipalities of AP Vojvodina According to Multidimensional Denominator of the Goods of Cattle Breeding Production, Journal of Agricultural Sciences, 48(2), 217-226.

13. Nita, V. (2011). An extended approach to e-inclusion and its implications for Romania, Romanian Journal of European Affairs, 11(1), 63-80.

14. Official Gazette of the RS, No 109/09 and 46/10.

15. Simić, J., Bogdanović, J., Živković, D., Stevanović, S., Umićević, R. (1994). Tendencije $i$ karakteristike razvoja voćarstva u Republici Srbiji, Međunarodni naučni simpozijum Budućnost voćarstva u Jugoslaviji, Vučje.

16. Statistički godišnjak Srbije, Opštine u Srbiji, RZS, Beograd.

17. Stevanović, S. (2009): Razvoj tržišne proizvodnje u poljoprivredi Republike Srbije, Monografija, Društvo agrarnih ekonomista Srbije i Univerziteta u Beogradu, Poljoprivredni fakultet, Beograd, 1-222.

18. Stevanović, S., Milanović, M. (2016). Regional Characteristics of Market Production of Sugar Beet and Sunflower in Serbia, Marketing, 47(2), 137-147.

19. Tomić, D. (2008). Promene u potrošnjin voća u Srbiji i Crnoj Gori, Poljoprivreda i selo-ideje i inicijative, Društvo agrarnih ekonomista Srbije. Beograd, str. 184-191.

20. Tomić, D, Simonović, V. (2008). Međuzavisnost ratarske i stočarske proizvodnje, Poljoprivreda i selo-ideje i inicijative, Društvo agrarnih ekonomista Srbije, Beograd, str. 131-137.

21. Vlahović, B., Stevanović, S., Tomašević, D., Zelenjak, M. (2006). Agrarna proizvodnja u Republici Srbiji, Društvo agrarnih ekonomista Srbije, Beograd, str. 119-202. 


\section{REGIONALNA OBELEŽJA TRŽIŠNE PROIZVODNJE VOĆA I GROŽĐA U SRBIJI}

\section{Simo Stevanovićc ${ }^{14}$, Snežana Stevanovićc ${ }^{15}$, Svjetlana Janković-Šsjaja \\ Sažetak}

U radu je analizriana regionalna obeležja tržišne proizvodnje voća (na primeru jabuke i šljive) i grožđa po oblastima Srbije u periodu 1976-2015. godine. Grupisanje oblasti u Srbiji prema stepenu tržišne proizvodnje voća i grožđa u 2015. godini izvršeno je klaster analizom na osnovu 6 obeležja proizvodnje, 5 obeležja kapaciteta i 5 obeležja razvijenosti.

Prema podacima za 2015. godinu, stepen tržišnosti jabuka u Srbiji iznosio je 47.7\%, šljiva 15.9\% i grožđa 18.3\%. Region Srbija-Sever suficitaran je u proizvodnji jabuka, a deficitaran u proizvodnji šljiva (-181.7\%) i grožđa (-99.1\%). Region Srbija-Jug suficitaran je u proizvodnji analiziranih vrsta voća (jabuka 43.0\% i šljiva 50.9\%) i grožđa (45.2\%).

Ključne reči: tržišna proizvodnja voća, privredna razvijenost, I-odstojanje, klaster analiza.

14 Dr Simo Stevanović, Redovni profesor, Univerzitet u Beogradu, Poljoprivredni fakultet, Nemanjina 6, 11080 Beograd, Republika Srbija, tel.: +381114413418, e-mail: simo. stevanovic@agrif.bg.ac.rs.

15 Dr Snežana Stevanović, Docent, Univerzitet u Beogradu, Poljoprivredni fakultet, Nemanjina 6, 11080 Beograd, Republika Srbija, tel.: +381114413226, e-mail: smasovic@agrif.bg.ac.rs.

16 Dr Svjetlana Janković-Šoja, Docent, Univerzitet u Beogradu, Poljoprivredni fakultet, Nemanjina 6, 11080 Beograd, Republika Srbija, tel.: +381114413419, e-mail: svjetlanajs@agrif.bg.ac.rs. 